\title{
Triassic-Jurassic sediments and multiple volcanic events in North Victoria Land, Antarctica: A revised stratigraphic model
}

\author{
R. Schöner, ${ }^{1}$ L. Viereck-Goette, ${ }^{1}$ J. Schneider, ${ }^{2}$ and B. Bomfleur ${ }^{3}$ \\ ${ }^{1}$ Friedrich-Schiller-Universität Jena, Institut für Geowissenschaften, Burgweg 11, 07749 Jena, Germany (robert.schoener@uni-jena.de ; \\ lothar.viereck-Goette@uni-jena.de) \\ ${ }^{2}$ TU Bergakademie Freiberg, Institut für Geologie, Bernhard-von-Cotta Str. 2, 09596 Freiberg, Germany (schneidj@geo.tu-freiberg.de) \\ ${ }^{3}$ Westfälische Wilhelms-Universität Münster, Geologisch-Paläontologisches Institut, Hindenburgplatz 57, 48143 Münster, Germany \\ (bennibomfleur@gmx.de)
}

\begin{abstract}
Field investigations in North Victoria Land, Antarctica during GANOVEX IX (2005/2006) allow the revision of the Triassic-Jurassic stratigraphy of $\sim 300 \mathrm{~m}$ thick continental deposits in between the crystalline basement and the Kirkpatrick lava flows of the Ferrar Group. The lower stratigraphic unit (Section Peak Formation) is characterised by braided river-type quartzose sandstone deposits with intercalations of shale and coal occurring at the top. It is overlain by a homogeneous unit of reworked tuffs composed of fine-grained silicic shards, quartz and feldspar (new name: "Shafer Peak Formation"). These deposits can be correlated with parts of the Hanson Formation in the Central Transantarctic Mountains and require a distal yet unknown source of massive silicic volcanism. Clastic products of mafic volcanic eruptions, formerly described as a separate stratigraphic formation (Exposure Hill Formation), occur within local diatreme structures as well as intercalated at various stratigraphic levels within the sedimentary succession. These dominantly hydroclastic eruptions are the first subaerial expression of Ferrar magmatism. The initial Kirkpatrick lavas/pillow lavas were generated from local eruptive centres and again may be overlain by thin sediments, which are covered by the thick plateau lava succession known throughout the Transantarctic Mountain Range.
\end{abstract}

Citation: Schöner, R., L. Viereck-Goette, J. Schneider and B. Bomfleur (2007), Triassic-Jurassic sediments and multiple volcanic events in North Victoria Land, Antarctica: A revised stratigraphic model, in Antarctica: A Keystone in a Changing World - Online Proceedings of the 10th ISAES, edited by A.K. Cooper and C.R. Raymond et al., USGS Open-File Report 2007-1047, Short Research Paper 102, 5 p.; doi:10.3133/of2007-1047.srp102

\section{Introduction}

The Ferrar Province in Antarctica is one of the large igneous provinces that was related to the break-up of the supercontinent Gondwana during the Mesozoic. In North Victoria Land (NVL), South Victoria Land (SVL), and the Central Transantarctic Mountains (CTM), Ferrar Province related igneous activity culminated in the effusion of the Early Jurassic Kirkpatrick plateau lava flows, developing a thickness of up to $\sim 1000 \mathrm{~m}$. This volcanic succession overlies $\sim 300 \mathrm{~m}$ thick continental siliciclastic and volcaniclastic sediments, which are the focus of this paper.

Previous investigations have shown that the Kirkpatrick lava flows are pre-dated by mafic volcaniclastic breccias and tuff breccias in the CTM (Prebble Formation; e.g., Barrett et al., 1986; Elliot, 2000), in SVL (Mawson Formation; e.g., Ballance and Watters, 1971; McClintock and White, 2006) and in NVL (Exposure Hill Formation; e.g., Elliot et al., 1986). Only in the CTM these volcaniclastic breccias are underlain by volcaniclastics of the Hanson Formation, a silicic tuffaceous unit thought to be Early Jurassic in age (Elliot, 1996). Potential correlative silicic tuffaceous sand/siltstones are also known from SVL and NVL where they form megaclasts in the deposits of the Mawson and Exposure Hill Formation (Elliot et al., 1986; Elliot and Hanson, 2001). These rocks are underlain by quartzose sandstones of the Victoria Group (Beacon Supergroup) in the entire Transantarctic Mountains (e.g., Collinson et al., 1994). The quartzose sandstone unit in NVL is referred to as Section Peak Formation and interpreted as braided river deposits of Middle to Late Triassic (e.g., Collinson et al., 1986; Tessensohn and Mädler, 1987) or even Early Jurassic age (e.g., Norris, 1965; Pertusati et al., 2006).

Although the contacts between siliciclastic rocks of the Victoria Group and the overlying volcaniclastic units appear to be concordant, e.g. in the Beardmore Glacier region, CTM (Elliot, 2000), the true contact relationships are often uncertain. In SVL, volcaniclastic deposits that had previously been described as lahars filling up palaeotopography (Ballance and Watters, 1971; Elliot and Hanson, 2001) have recently been re-interpreted as components of vent complexes and magmaticallygenerated collapse structures (White and McClintock, 2001; Elliot et al., 2006). In NVL, the Exposure Hill Formation is regarded as a separate stratigraphic unit on top of the siliciclastic sequence (Elliot et al., 1986; Elliot et al., 2006), but the contacts were not yet investigated systematically. Based on new field investigations during the 9th German North Victoria Land Expedition (GANOVEX IX, 2005/2006), we describe here the contact relationships of siliciclastic and volcaniclastic rocks underlying the Kirkpatrick lava flows, and suggest a revised model for the Triassic to Early Jurassic stratigraphy of NVL.

\section{The Triassic to Early Jurassic succession in North Victoria Land}

28 representative outcrops of the Triassic to Early Jurassic sedimentary succession in southern NVL were measured in detail (Fig. 1). The base of this succession is exposed at several localities along the edge of the polar plateau as well as at Stewart Heights and Vulcan Hills. The top is exposed in the Deep Freeze Range and in the 
Mt. Carson area. More or less continuous sections from the basement to the Kirkpatrick lava flows are only exposed in the Deep Freeze Range.

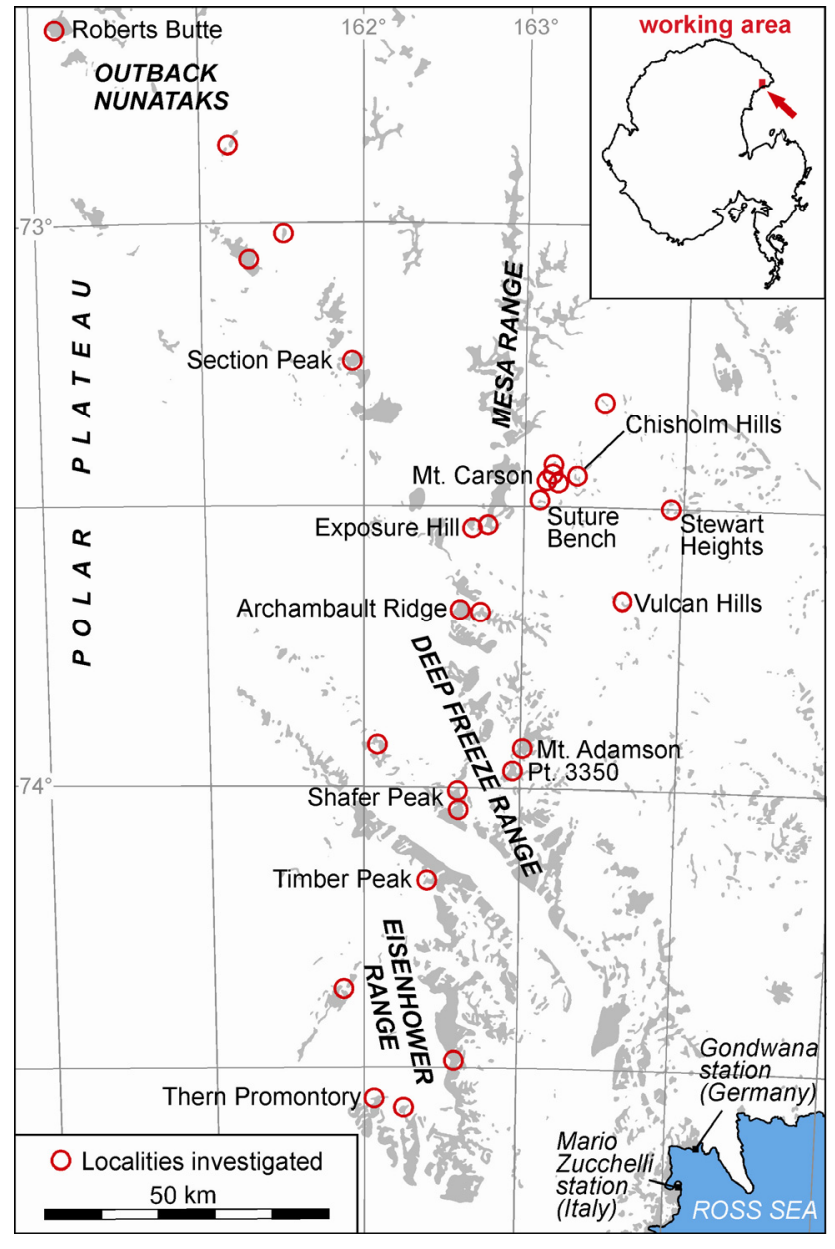

Figure 1. Working area and localities investigated in North Victoria Land during GANOVEX IX (2005/2006). Rock outcrops are grey, ice and snow cover white. Map based on GANOVEX-Team (1987).

\section{Section Peak Formation (SPF)}

The base of the Section Peak Formation (SPF) is a non-conformity with evidence of local relief on a meter scale. The underlying basement consists of Precambrian metamorphic rocks (mainly schists) and Ordovician granitic rocks (Granite Harbour Intrusives). Sandstones and thin conglomerates overlie the weathered crystalline basement in the Deep Freeze Range (Fig. 1) and further north. In Eisenhower Range, south of the Priestley Glacier, basal conglomerates may reach thicknesses of at least $60 \mathrm{~m}$.

The majority of the $\sim 200-250 \mathrm{~m}$ thick SPF is represented by white to yellowish-grey, medium- to coarse-grained quartzose sandstones with typically large scale trough cross-bedding. The sandstones are composed of quartz, feldspar and a variety of rock fragments including volcanic clasts. Pelitic interbeds are very rare. Towards the upper part of the SPF, the lithology tentatively becomes more variable. Around Shafer Peak and Timber Peak (Fig. 1), sandstone sheets of 8-15 m thickness are interbedded with fine-grained carbonaceous sand-/siltstones, minor lacustrine claystones, and coal layers. Plant fossil assemblages found at Vulcan Hills (see also Tessensohn and Mädler, 1987) and at Timber Peak are dominated by the seedfern Dicroidium. In the field, the sandstones of the upper SPF are hardly distinguishable from sandstones of the lower part of the SPF. However, only the uppermost tens of metres of the SPF contain local interbeds of fine-grained sandstones to siltstones that comprise silicic pyroclastic shards.

\section{Shafer Peak Formation (SHF, new)}

We propose the name "Shafer Peak Formation" (SHF) for the upper stratigraphic unit that is exposed around Mt. Carson and in the Deep Freeze Range. It can only be briefly described here; a more detailed, formal description is in preparation. The most complete and well exposed section has been measured at the N-ridge of Shafer Peak above $3200 \mathrm{~m}$, which is suggested as type section. It is made up of fine-grained, light grey to light brown tuffaceous sandstones and siltstones with a total thickness of $53 \mathrm{~m}$. A mafic sill intruded the section in about $28 \mathrm{~m}$ above the base of the SHF. Musumeci et al. (2006) described these sediments as "whitish quartzose sandstones with ash particles", and included them into the Exposure Hill Formation, a concept which is not supported here for reasons discussed below.

Characteristic components of the tuffaceous deposits are silicic glass shards along with quartz and feldspar. Most abundant sedimentary textures are ripple crosslamination, climbing ripples, and horizontal lamination, indicating reworking of rhyolitic tephra. Thin, greenishgrey pelite horizons and layers rich in pelitic intraclasts are frequently interbedded. Plant fossils are concentrated in isolated horizons and are typically highly fragmented. They are dominated by cycadophytes and dipterid ferns, whereas Dicroidium is totally absent.

In the area around Mt. Carson, the base of the SHF is not exposed or obscured by mafic intrusions. At Shafer Peak N-ridge, the SHF rests on thin grey-black lacustrine pelites that overlie mafic volcaniclastic deposits (see below). We define the base of the SHF as the sharp surface above which fine-grained tuffaceous sand/siltstone are dominant and siliciclastic sandstones are absent. The SHF is overlain by Ferrar Group lava flows or pillow lavas, although mafic volcaniclastics may be interbedded (see below and Fig. 2).

\section{Sills}

Mafic sills of up to $300 \mathrm{~m}$ cumulative thickness intruded the sedimentary succession in the entire study area (Fig. 1). Two generations of sill-emplacement can be distinguished: (a) earlier massive, vertically jointed sills with on $\mathrm{km}$-scale constant intrusion levels and red oxidised weathering crusts, and (b) younger dark grey to black sills, which are partly discordant and change 
horizons within the succession. At planar contacts with intruded siliciclastic sediments, sills developed thin chilled margins. In contrast, contacts with the tuffaceous deposits of the SHF are commonly highly irregular and in some cases even pillow-like. Peperitic products derived from fluidisation of unconsolidated tuffaceous sediments are widespread in the area of Mt. Carson in the vicinity of sill or plug intrusions into the SHF (Viereck-Goette et al., 2007, this volume).

\section{Exposure Hill Type (EHT) events}

At several localities in NVL, especially in the area around the southern Mesa Range, chaotic volcaniclastic breccias as well as block- and lapilli-bearing tuffs may cross-cut the sedimentary succession over an exposed thickness of several tens to $>150 \mathrm{~m}$. The breccias contain dense angular as well as scoriaceous juvenile igneous clasts, and sedimentary rafts of the SPF and SHF. These units are interpreted as (partly multiple) diatreme fillings resulting from local hydromagmatic explosive events (Viereck-Goette et al., 2007, this volume). Field observations suggest that all transitions exist from (a) irregular-shaped meter-sized apophyses of sills over (b) plugs diverging from sills that may consist of brecciated magma to (c) diatremes.

The same types of clasts, plus accretionary lapilli, occur also within stratified intraformational volcaniclastic sediments up to about $50 \mathrm{~m}$ thickness. These sediments commonly show a fining upward trend from coarse blockrich tuffs to (lapilli-)tuffs, which are partly reworked. Tuffaceous fine-grained sand- to siltstones similar to the material occurring in the SHF may be interbedded in the upper part. Thin fossiliferous lacustrine black shales are locally developed on top of such volcaniclastic units.

Intraformational mafic volcaniclastic sediments have been found at different stratigraphic levels at various localities, and they are laterally not continuous. The first signs of local explosive eruptions are registered by ashsized vesicular, commonly reddish particles of altered glass occurring several meters below the uppermost quartz sandstone beds exposed in the Chisholm Hills. These rocks are tentatively placed in the uppermost part of the SPF. Block- and lapilli-bearing tuffs are abundant in between quartz sandstones (SPF) and reworked silicic tuffs (SHF) at outcrops in the Deep Freeze Range. Most widespread are mafic volcaniclastic deposits occurring above $35-50 \mathrm{~m}$ of exposed SHF sediments (Mt. Carson area, SW-ridge of Gair Mesa, Shafer Peak), including the horizons already described by Elliot et al. (1986).

These observations imply that mafic volcaniclastics were generated at various localities through multiple local events and do not form a discrete stratigraphic unit in the sense of a formation (Fig. 2). We therefore suggest the use of the term "Exposure Hill Type (EHT) events" instead of "Exposure Hill Formation" (Elliot et al., 1986), although the Exposure Hill type locality itself represents a diatreme and is hence not representative of intraformational deposits.
The mixed siliciclastic/volcaniclastic successions are typically capped by pillow lavas or subaerial lava flows. Field observations suggest that these initial Kirkpatrick lavas erupted from local centres such as the Mt. Carson volcanic neck (cf. Fig. 1). Intercalations of thin fossiliferous lake sediments in between the initial lavas and the regional-scale plateau lava flows suggest that this major volcanic episode started with low effusion rates.

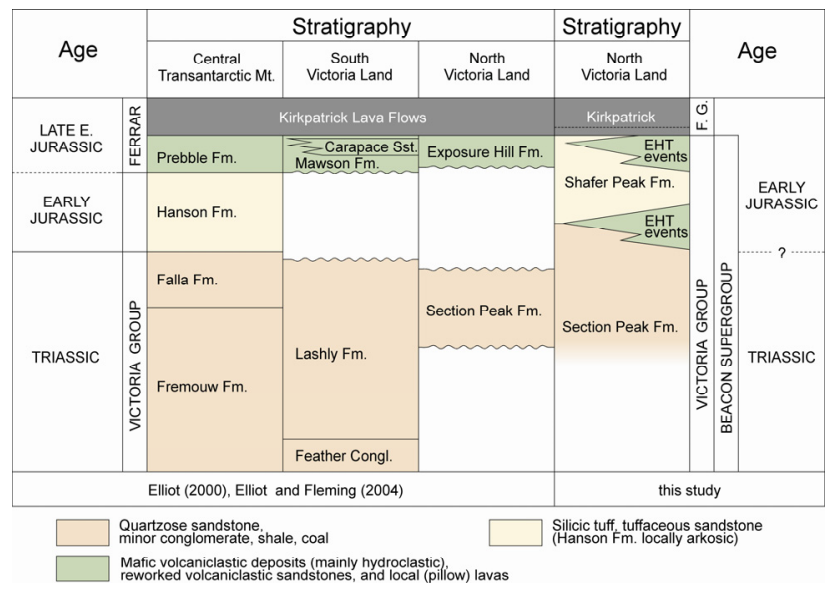

Figure 2. Stratigraphy of the Triassic to Lower Jurassic deposits in the CTM, SVL, and NVL according to previous studies (Elliot, 2000; Elliot and Fleming, 2004) and this study.

\section{Discussion}

The SPF represents deposits of a large-scale braided fluvial drainage system several $10 \mathrm{~s}$ of $\mathrm{km}$ wide, with decreasing flow velocities towards the top. Dicroidiumdominated floras confirm the Triassic age for the SPF proposed earlier (e.g., Gair et al., 1965; Tessensohn and Mädler, 1987). The precise age range is still uncertain due to the lack of high-resolution biostratigraphic data near the base and limited data near the top. Consequently, the SPF may well include the Early Jurassic as suggested by palynomorphs (Norris, 1965; Pertusati et al., 2006). Contrary to all previously published evidence, Di Guilio et al. (1997) concluded that the SPF must be entirely Jurassic in age, based on their interpretation that mafic igneous layers in the SPF are lava flows. However, our reinvestigation of the same outcrops indicates that all observed mafic igneous units present within the SPF are intrusive in nature.

Occasional layer-wise concentrations of silicic shards within quartzose sandstones provide evidence for contemporaneous silicic volcanism in the uppermost SPF. However, grain size characteristics point to distal volcanic sources. Comparable interbeds have also been reported from the uppermost Lashly Formation in SVL (Elliot et al., 2006) and the lower Hanson Formation in the CTM (Elliot, 2000). The base of the latter is described as an abrupt change from the Dicroidium-bearing siliciclastic sequence (Falla Formation) to silicic tuffaceous beds at an unconformity (Elliot, 1996). The first occurrence of silicic 
shards is not a useful stratigraphic boundary in NVL, because shard-bearing and shard-free sediments are macroscopically not always easy to distinguish, nor has it much stratigraphic significance in a braided river environment due to the low preservation potential and reworking.

In contrast, the SHF as defined above is a mappable unit in NVL, which can be correlated at least between the Deep Freeze Range and the Mt. Carson area. Lithologies and sedimentary textures indicate that well-sorted tuffaceous material was re-deposited dominantly by fluvial processes. The stratigraphic position, the dominance of cycadophytes and dipterid ferns along with the lack of Dicroidium-remains suggest an Early Jurassic age for the SHF. Based on the compositional and textural similarity, and considering the lithostratigraphic position, it can be interpreted as a stratigraphic equivalent of the upper Hanson Formation in the CTM. Lithological equivalents are also known from rafts in volcaniclastic rocks in SVL (e.g. Bradshaw, 1987). Hence remarkably similar (reworked) silicic ash material of comparable grain size was deposited in an area extending more than $1000 \mathrm{~km}$ from the CTM to NVL. Considering the small grain sizes (ash) and sorting characteristics, this suggests an airfall origin of windblown ash, generated by distal large-volume (ultraplinian) eruptions. Although the magmatic source can not be reasoned on the basis of geochemical and isotopic studies so far, the Early Jurassic Mt. Poster Formation (eruption age $<190 \mathrm{Ma}$ ) in the southern Antarctic Peninsula (Hunter et al., 2006) would provide a potential rhyolitic volcanic source, presumed that westerly palaeowind directions were dominant as evident from the adjacent South African part of Gondwana (e.g., Smith et. al, 1993).

Local hydrovolcanic eruptions (Exposure Hill Type events) are related to interaction of mafic magma with ground water or wet sediments, respectively, but also involve a minor pyroclastic component (cf. ViereckGoette et al., 2007, this volume). A chaotic diatreme facies, cross-cutting the sedimentary strata, can be distinguished from intraformational, non-continuous volcaniclastic deposits, both including the same types of igneous and sedimentary clasts. Although multiple intersecting vents are also evident from SVL (White and McClintock, 2001), the stratigraphic relationships to the sedimentary succession is ambiguous. In contrast, NVL provides evidence for multiple local hydrovolcanic events during the Early Jurassic, preceding the major effusion of the Kirkpatrick plateau lava flows.

\section{Conclusions}

The results of our investigations allow the revision of the Mesozoic stratigraphy of North Victoria Land. We subdivide the succession in between the sub-Beacon unconformity and the base of the Kirkpatrick lava flows by lithological means into two stratigraphic units:
1. The lower stratigraphic unit of up to $\sim 200-250 \mathrm{~m}$ thickness (Section Peak Formation, SPF) is dominated by medium- to coarse-grained quartzose sandstones.

2. The upper stratigraphic unit of about $50 \mathrm{~m}$ thickness is dominated by fine-grained tuffaceous sandstones to siltstones (reworked tephra). We introduce the term "Shafer Peak Formation" (SHF) for this unit. Most likely the SHF correlates with the upper part of the Hanson Formation in the CTM, requiring a distal, explosive volcanic source of silicic composition and Early Jurassic age.

Mafic volcaniclastics with cross-cutting relationships towards the sedimentary country rocks are re-interpreted as representing diatreme fillings of dominantly hydrovolcanic eruptions. Additionally, intraformational mafic volcaniclastics concentrate at two stratigraphic levels in the SHF and the uppermost SPF. These units do not form a single, continuous horizon and should be labelled Exposure Hill Type (EHT) "events" rather than viewing them as a stratigraphic "formation".

Acknowledgments. We are grateful to the Bundesanstalt für Geowissenschaften und Rohstoffe (BGR), Hannover, Germany, for inviting us to join the expedition GANOVEX IX, and for generous logistical support during the expedition. Prior to the field season David Elliot kindly provided us with information on various outcrops in North Victoria Land. We thank James Collinson and Harald Stollhofen for their constructive reviews. The ongoing research project is funded by the German Research Foundation (DFG), grants VI 215/6-1, SCHN 408/111, KE 584/12-1 and GA 457/11-1.

\section{References}

Ballance, P. F. and W. A. Watters (1971), The Mawson Diamictite and the Carapace Sandstone, Formations of the Ferrar Group at Allan Hills and Carapace Nunatak, Victoria Land, Antarctica, N. Z. J. of Geology and Geophysics, 14, 512-527.

Barrett, P. J., D. H. Elliot and J. F. Lindsay (1986), The Beacon Supergroup (Devonian-Triassic) and Ferrar Group (Jurassic) in the Beardmore Glacier area, Antarctica, in Geology of the central Transantarctic Mountains, edited by M. D. Turner and J. F. Splettstoesser, Antarctic Research Series, American Geophysical Union, 36, 339-453.

Bradshaw, M. A. (1987), Additional field interpretation of the Jurassic sequence at Carapace Nunatak and Coombs Hills, South Victoria Land, Antarctica, N. Z. J. of Geology and Geophysics, 30, 37-49.

Collinson, J. W., C. D. Pennington and N. R. Kemp (1986), Stratigraphy and Petrology of Permian and Triassic fluvial deposits in northern Victoria Land, Antarctica, Antarctic Research Series, American Geophysical Union, 46, 211-242.

Collinson, J. W., J. L. Isbell, D. H. Elliot, M. F. Miller, J. M. G. Miller and J. J. Veevers (1994). Permian-Triassic Transantarctic basin, in Permian-Triassic Pangean Basins and Foldbelts along the Panthalassan Margin of Gondwanaland, edited by J. J. Veevers and C. M. Powell, Geol. Soc. Am. Mem., 184, 173-222.

Di Giulio, A., R. Casnedi, A. Ceriani, A. Ortenzi, and A. Rossi, (1997): Sandstone composition of the Section Peak Formation (Beacon Supergroup, Northern Victoria Land, Antarctica) and relations with the Ferrar Group Volcanics, in The Antarctic Region: Geological Evolution and Processes, edited by C. A. Ricci, Proceedings of the VII International Symposium on Antarctic Earth Sciences, 297-304, Siena.

Elliot, D. H. (1996), The Hanson Formation: a new stratigraphical unit in the Transantarctic Mountains, Antarctica, Antarct. Sci., 8, 389394.

Elliot, D. H. (2000): Stratigraphy of Jurassic pyroclastic rocks in the Transantarctic Mountains, J. African Earth Sci., 31, 77-89.

Elliot, D. H., M. A. Haban and M. A. Siders (1986), The Exposure Hill Formation, Mesa Range, in Geological Investigations in Northern 
Victoria Land, edited by E. Stump, AGU Antarctic Research Series, American Geophysical Union, 46, 267-278.

Elliot, D. H. and R. E. Hanson (2001), Origin of widespread, exceptionally thick basaltic phreatomagmatic tuff breccia in the Middle Jurassic Prebble and Mawson Formations, Antarctica, J. Volc. Geotherm. Res., 111, 183-201.

Elliot, D. H. and T. H. Fleming (2004), Occurrence and dispersal of magmas in the Jurassic Ferrar Large Igneous Province, Antarctica, Gondwana Research, 7, 223-237.

Elliot, D. H., E. H. Fortner and C. B. Grimes (2006), Mawson Breccias Intrude Beacon Strata at Allan Hills, South Victoria Land: Regional Implications, in Antarctica: Contributions to global earth sciences, edited by D.K. Fütterer, D. Damaske, G. Kleinschmidt, H. Miller, F. Tessensohn, pp. 291-298, Springer, Berlin, Heidelberg, New York.

Gair, H. S., G. Norris and J. Ricker (1965), Early Mesozoic microfloras from Antarctica, N. Z. J. of Geology and Geophysics, 8, 231-235.

GANOVEX-Team (1987), Geological Map of North Victoria Land, Antarctica, 1:500 000, Geol. Jb., B 66, 7-79.

Hunter, M. A., T. R. Riley, D. J. Cantrill, M. J. Flowerdew and I. L. Millar (2006), A new stratigraphy for the Latady Basin, Antarctic Peninsula: Part 1, Ellsworth Land Volcanic Group, Geol. Mag., 143, 777-796.

McClintock, M. and J. D. L. White (2006), Large phreatomagnetic vent complex at Coombs Hills, Antarctica: Wet, explosive initiation of flood basalt volcanism in the Ferrar-Karoo LIP, Bull. Volcanol., 68, 215-239.

Musumeci, G., P. C. Pertusati, C. Ribecai, and M. Meccheri (2006), Early Jurassic fossiliferous black shales in the Exposure Hill Formation, Ferrar Group of Northern Victoria Land, Antarctica, Terra Antarctica Reports, 12, 91-98.

Norris, G. (1965), Triassic and Jurassic miospores and acritarchs from the Beacon and Ferrar groups, Victoria Land, Antarctica, N. Z. J. of Geology and Geophysics, 8, 236-277.

Pertusati, P. C., C. Ribecai, R. Carosi, and M. Meccheri (2006), Early Jurassic Age for Youngest Beacon Supergroup Strata Based on Palynomorphs from Section Peak, Northern Victoria Land, Antarctica, Terra Antarctica Reports, 12, 99-104.

Smith, R. M. H., P. G. Eriksson, and W. J. Botha (1993), A review of the stratigraphic and sedimentary environments of the Karoo-ages basins of Southern Africa, J. African Earth Sci., 16, 143-169.

Tessensohn, F. and K. Mädler (1987), Triassic Plant Fossils from North Victoria Land, Antarctica, Geol. Jb., B66, 187-201.

Viereck-Goette, L., R. Schöner, B. Bomfleur, and J. Schneider (2007, this volume): Multiple shallow level sill intrusions coupled with hydromagmatic explosive eruptions mark the initial phase of Ferrar Magmatism in North Victoria Land, Antarctica.

White, J. D. L. and M. K. McClintock (2001), Immense vent complex marks flood-basalt eruption in a wet, failed rift: Coombs Hills, Antarctica, Geology, 29, 935-938. 